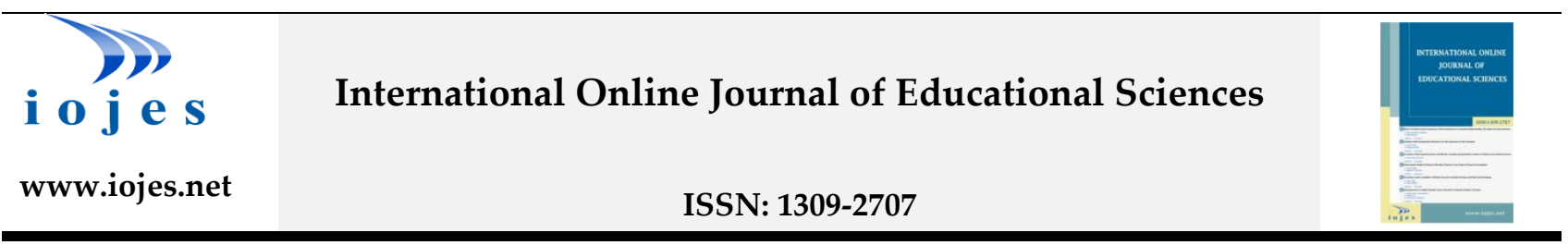

\title{
The Effect of Digital Storytelling on Digital Literacy Skills of The 7th Graders at Secondary School*
}

\author{
Research Article
}

\section{Aysun EROGLU1, Alpaslan OKUR²}

${ }^{1}$ Kafkas University University, Faculty of Dede Korkurt Education, Department of Turkish Education, ORCID: 0000-0003-1047-8748

${ }^{2}$ Sakarya University University, Faculty of Education, Department of Turkish Education, ORCID: 0000-0002-2868-063X

To cite this article: Eroglu, A., \& Okur, A. (2021). The effect of digital storytelling on digital literacy skills of the 7th graders at secondary school. International Online Journal of Educational Sciences, 13 (4), 1235-1253.

\begin{tabular}{|c|c|}
\hline ARTICLE INFO & ABSTRACT \\
\hline Article History: & $\begin{array}{l}\text { The purpose of this study was to seek into the effect of digital storytelling on digital literacy } \\
\text { in the 7th graders at secondary school. The quasi-experimental design among quantitative }\end{array}$ \\
\hline Received: 24.03 .2021 & $\begin{array}{l}\text { methods was employed and two groups were designed through simple random sampling. } \\
\text { The study group was composed of } 35 \text { students in Grade } 7 \text { at a private secondary school in the }\end{array}$ \\
\hline Available online: & Central District of Kars. Before starting the research, permissions of the ethics committee and \\
\hline 10.06 .2021 & $\begin{array}{l}\text { governorship were obtained for the scale to be used in the research. Digital Literacy Scale and } \\
\text { personal information form were used as data collection tools. Mann Whitney U-Test for } \\
\text { intergroup analysis and Wilcoxon signed-rank test for intragroup analysis among non- } \\
\text { parametrical statistics were used. As a result of analysis; it was found that there is a significant } \\
\text { difference in favour of the experiment group in terms of post-test scores of digital literacy } \\
\text { among the groups after the experiment. At the same time; it was found that there is a } \\
\text { significant difference in favour of the post-test between the pre-test and post-test scores of the } \\
\text { experimental group. These findings revealed that the digital storytelling creation process } \\
\text { contributed to the development of students' digital literacy skills. Accordingly, it is suggested } \\
\text { that digital storytelling can be included in curriculums and the effects of digital storytelling } \\
\text { can be evaluated with different methods and techniques. }\end{array}$ \\
\hline
\end{tabular}




\section{Introduction}

Today, with technological developments, there are obvious changes in most areas of human life. Education is one of the areas where these changes manifest themselves. It is seen that the qualifications of the teachers who carry out education, the skills expected from the students, the educational environments, and the tools used in education are reshaped with technological developments. For example, in a study conducted by MEB Education Research and Development Department (2011), "21. Century Student Profile? " among the answers given to the question is "should know technology". Another example is that the new Turkish Lesson Curriculum (Grades 1-8) emphasizes the effective use of technology in lessons compared to the old Turkish Course Curriculum (Grades 6-8) more, and the new one emphasizes the ability of students to adapt to technological developments and to acquire these skills more (MEB, 2018; MEB, 2006). In the competencies section of this curriculum, students at both national and international level; digital competence (p. 3-4) is mentioned among the skills they will need in their personal, social, academic, and business life (MEB, 2018). In the teaching-learning approach part of this curriculum, it has been mentioned that digital resources can be used for the applications and activities in the lessons. In the themes and topic suggestions section of this curriculum, there are "information literacy, multiple literacies, digital literacy, e-book, critical literacy, z-book, z-library, etc." under the heading of reading culture (MEB, 2018; p.14). It has been noticed that technology is included in the curriculum as a source of information in the acquisitions for grades 3-8, "Evaluates the media texts. It is ensured that the messages given by the internet, cinema and television are evaluated." Parallel to this, "questions the reliability of information sources. a) It is ensured that the reliability of internet / written (magazine, book, brochure, newspaper, etc.) sources are questioned. b) It is emphasized that the websites with "edu" and "gov" extensions are mainly used in scientific studies. " (MEB, 2018; p. 40-4448) have emphasized that middle school students acquire the skills to question the reliability of the source while using the internet as a source of information. Although it seems difficult to provide $100 \%$ security in the computer and internet environment, a high level of security can be achieved by taking some measures (BTK, 2018). One of the ways to ensure security in the internet environment is digital literacy. Digital literacy is a skill that is among the 21st-century skills and is also included in the curriculum (Günay \& Şişman, 2018).

Technological developments have brought new nomenclatures in the field of literacy: media literacy, digital literacy, technology literacy, global literacy... It is seen that the storytelling we use in daily life or education and training is shaped and named in parallel with technological developments: digital storytelling. Digital storytelling is the result of the combination of story text and various multimedia tools such as painting, photography, sound, music, effects, and video (Alexandar, 2011; Foley, 2013; Frazel, 2010; Lambert, 2010; Lammers, 2012; Robin, 2006). Thanks to digital storytelling, students can improve their digital literacy skills outside of the information technology course, as well as learn different information and have fun (Alexandar, 2011; Ayvaz Tunç, 2016; Balaman Uçar, 2016; Brown, Bryan, \& Brown, 2005; Chung, 2006; Churchill, 2016; Davis, 2004; Demirer, 2013; Dogan, 2007; Foley, 2013; Frazel, 2010; Heo, 2009; Hett, 2012; Jakes \& Brennan, 2005; Kajder, 2004; Lambert, 2010; Lammers, 2012; Robin, 2006, Robin, 2008; Sadik, 2008; Sharp, Garofalo, \& Thompson, 2004; Wang \& Zhan, 2010). It has been a matter of curiosity whether digital stories affect the digital literacy skills of students who take the secondary school Turkish course, as it is mentioned in the curriculum that they can acquire digital literacy skills, which is among the skills expected from 21st-century children, outside of technology lessons.

Parallel to the developing technology, it is expected that the children of the 21st century keep up with the times in the 21st century. These children are asked to use developing technology correctly and efficiently. It is expected to do this not in a single lesson or in a single area but using multi-field skills. In other words, the new system states that a student should not be content with only reading, writing, and grammar in Turkish lessons. Since digital storytelling contributes to students' traditional storywriting skills, as well as their ability to use technology, it serves some of the achievements that new 
curriculums expect students to acquire. Therefore, it has aimed to investigate the effect of digital stories on the digital literacy skills of students who took the secondary school 7th-grade Turkish course.

Is it important to use digital storytelling in Turkish lessons or mother tongue teaching lessons or language teaching? Yes, it does. Because the basis of digital storytelling is based on the traditional story writing process. The traditional stories are available in all grades 1-8 in the Turkish lesson program. Writing stories is one of the ways students express themselves. However, digital storytelling is important because students who have difficulties in writing can express themselves with photographs, pictures, music, and voices in addition to text (Foley; 2013; Vasudevan, Schultz, \& Bateman, 2010). What keeps this study updated is that there is no study directly examining the relationship between digital literacy skills expected of 21st-century children and digital storytelling that contributes to this skill in the curriculum organized in parallel with developing technology. Therefore, this study is expected to both fill the academic gap in the field and to ensure that digital story applications, whose history does not date back very far, progress systematically and by the requirements of the age. It is hoped that the results obtained from this study will make an academic contribution to the history of digital storytelling, be included in the curriculum as an activity, and be applied in lessons.

\section{Story}

A story is a verbal or written narration of an event, a type of prose that tells about real or designed events (Doğan, 2005; TDK, tdk.gov.tr). It is a genre of literature that tells people's own experiences (Simmons, 2008), and events already experienced or possible to be experienced (Akbayır, 2007; Göçer, 2014; Kavcar, Oğuzkan \& Aksoy, 2003) without giving details, by pointing out place, time and person (Babacan, 2008). If children need to be taught something, stories are one of the best ways because children become convinced of learning the targeted topic by being influenced by well-built stories (Eroğlu, 2020a). However, the stories should not just be composed of a random series of events. Since stories require a certain order and discipline, it is necessary to analyse each part of the story first and then to obtain a meaningful, consistent and logical whole from these parts (Temizkan, 2014). Because stories contribute to the development of children's interpretation, inference, organization, remembering, vocabulary, which develops their comprehension and expression skills (Akyol, 2006; Göçer, 2014; Temizyürek, 2003; Walsh \& Blewitt, 2006) and develop children's creativity (Taşkaya, 2017, Ed. A. Akkaya). Today, stories are recognized as an effective, meaningful, fun, and creative way to teach and improve learning. (Wang \& Zhan, 2010). The current version of this is digital storytelling.

\section{Digital storytelling}

Digital storytelling was first created by Joe Lambert and Dana Atchley as a non-profit arts organization in Berkeley, California, in the late 1980s. In the early 1990s, the Digital Media Center was opened in San Francisco with the participation of Nina Mullen to these two names, and then the name of this institution was changed to Digital Storytelling Center (Center For Digital Storytelling-CDS) in Berkeley in 1998 (StoryCenter; Chung, 2007; Robin, 2008; Karakoyun, 2014; Yamaç, 2015; Baki, 2015).

Although there are different definitions of digital stories, definitions are generally gathered around the idea of combining the art of storytelling with multimedia elements such as painting, sound, and video (Robin, 2006). Thanks to digital storytelling, students can use music, sound effects, video, and more to create multimedia presentations that improve their creativity, collaborative learning, and technology use skills (Frazel, 2010). The new generation of storytelling starts with digital storytelling, and these digital stories are created on a computer using pictures, sometimes adding music and sound files (Hett, 2012).

According to Robin (2006), there are many different types of digital storytelling; however, it is possible to categorize them into three large groups: 1 . Personal narrations, 2. Historic documentaries (stories expressing the dramatic events and helping us understand the past), 3. Stories are composed to inform the audience about a special concept or application or to teach that. 
The following seven elements are cited as a useful starting point for getting started with digital storytelling:

1. Point of View: What is the writer's point of view about the topic?

2. A Dramatic Question: A question to be answered at the end of the story.

3. Emotional Content: Serious issues that come alive in a personal and powerful way.

4. The Gift of Your Voice: A way to personalize the story to help the audience to understand the context.

5. The Power of the Soundtrack: Music or other sounds that support and embellish the story.

6. Economy: Using enough content to tell the story without overloading the viewer.

7. Pacing: it is associated with the economy but especially with how slowly or quickly the story progresses (Robin, 2006).

The following six steps are suggested in the process of creating digital storytelling:

1. Writing the story/script: The story is written, the scripts are revised according to the suggestions, and then finalized.

2. The student records the story with her/his own voice.

3. Images related to the story are searched and found from various sources.

4. Sound and visuals are combined.

5. Transition effects and background music can be added.

6. Once digital storytelling is created, it is presented or shared (Barrett, 2009).

In the digital storytelling creation process, if the above elements are considered, the process is efficient and fun. In this study, these elements and this process have been paid attention to. Also, the digital storytelling in this stud is meant to add visual, music, sound, and effects related to the story text to the process that starts with creating a story text in a Turkish lesson and combining them.

\section{Digital storytelling creation tools and software}

Equipment to help create digital storytelling in a lesson are desktops/laptops/tablet computers, audio, and video recorders, headphones, speakers, external (flash) memories, scanners, and projection devices (Baki, 2015; Demirer, 2013; Karakoyun, 2014; Qiongli, 2009, Ed. J. Hartley \& K. McWilliam; Robin, 2006). Main software to be applied in digital storytelling composition is PhotoStory3, Microsoft PowerPoint, Microsoft Windows Live Movie Maker, iMovie, Pinnacle Studio, Adobe Premiere Elements, Ulead VideoStudio, (Baki, 2015; Brenner, 2014; Bull \& Kajder, 2005; Dogan, 2007; Karakoyun, 2014; Robin, 20006; Robin \& McNeil, 2012).

\section{Factors preventing digital storytelling creation}

Examining the barriers to digital storytelling creation, it is whether students have the chance to access the technology required to create digital stories. Since this is the most basic problem, students must have access to technology. Another problem of digital storytelling creation is time. Learning technology takes time, but any education already takes time due to the nature of learning and teaching (Lammers, 2012). Another problem is the lack of knowledge of teachers and students in using technology. If the teacher does not have sufficient and necessary knowledge about using technology, the students will naturally be inadequately trained in using technology correctly and efficiently. Another obstacle to digital storytelling creation is the copyright issue. While creating digital stories for students, it can be tempting to use images and music they find online.

\section{Using digital storytelling in education}

Taking notice of the use of digital storytelling in educational life, it is realized that the digital stories created by the teacher can be used to enrich the existing lessons in a wider unit as a way to make abstract or conceptual content more understandable to facilitate discussion on a topic (Robin, 2006). Assigning homework suitable for digital story creation stages or applying this process in the course creates interest, attention, and motivation for students, and students' story writing, video creation, and editing skills are provided (Matthews, 2014; Sadik, 2008; Smeda, Dakich, \& Sharda, 2012; Stewart and Gachago, 
2016). In this process, when students start researching and tell their stories, their creativity skills also improve as they learn to use the library and the internet while analyzing and synthesizing a wide range of content (Frazel, 2010; Robin, 2006). Students participating in the digital storytelling process learn to organize their ideas, ask questions, and express their thoughts and form a comprehensive communication skill (Brown, Bryan, \& Brown, 2005; Hathorn, 2005; Lammers, 2012; Robin, 2006; Robin, 2008; Sadik, 2008). At the same time, since the digital storytelling creation process is an entertaining process that attracts the attention of students, it also increases student motivation, increases their academic success and increases digital literacy levels (Brown, Bryan, \& Brown, 2005; Çetin, 2021; Lammers, 2012; Özüdoğru \& Çakır, 2020; Saritepeci, 2021).

\section{Using digital storytelling in Turkish courses}

Digital storytelling can be used very easily in Turkish, social studies, life studies, painting, music, mathematics, science and technology, literature, geography lessons, or interdisciplinary studies (Demirer, 2013; Hett, 2012; Karakoyun, 2014). When we look into the use of digital storytelling in language lessons, it has been found that students' listening skills (Ciğerci, 2015; Türe Köse, 2019; Verdugo \& Belmonte, 2007), speaking skills (Shrosbree, 2008; Soler Pardo, 2014; Razmi, Pourali, \& Nozad, 2014), reading skills (Çiftci, 2019; Şentürk Leylek, 2018) and writing skills (Çıralı, 2014; Dayan, 2017; Gündüz, 2019; Soler Pardo, 2014; Stojke, 2009; Uslu, 2019; Yamaç, 2015) are improved. Digital storytelling, which is easy to use for both writing and speaking practice, can be a good tool to motivate students to use language effectively and efficiently both inside and outside the classroom (Reinders, 2011). The effect of digital storytelling on students' story writing skills, writing anxiety, writing selfefficacy and writing attitudes in the 6th-grade Turkish course (Baki, 2015), the effect of using digital storytelling in Turkish course on academic achievement, motivation and permanence (Özerbaş \& Öztürk, 2017), the effect of 4th graders' writing skills in Turkish course (Dayan \& Girmen, 2018), the effect on students' literacy skills and viewpoints in learning Turkish (Yılmaz, Üstündağ, Güneş, \& Çalışkan, 2017), Turkish teacher candidates' metaphorical perceptions towards digital storytelling (Eroğlu, 2020b), the effect of attitude towards story writing (Eroğlu \& Okur 2020) have been investigated, and positive results have been obtained.

\section{Digital Literacy}

Students need essential skills to share their ideas on digital media, to communicate with others and access digital texts, or to represent certain ideas in digital media (Frazel, 2010; Ohler, 2006). One of these skills is digital literacy skill. This skill plays an important role in students' primary school, secondary school, and university education (Koltay, 2011). Digital literacy is the awareness, attitude, and ability of individuals to use digital tools appropriately (Lankshear \& Knobel, 2008; Martin \& Grudziecki, 2006). Digital literacy is the ability to understand and integrate information in many formats that the computer can present (Pool, 1997). On the other hand, Eshet (2002) emphasized that digital literacy is a special way of thinking and how the information obtained should be evaluated beyond obtaining information on the internet requires the ability to choose between useful and useless information. Since digital literacy is seen as a prerequisite for creativity, innovation, and entrepreneurship, it is thought that individuals cannot fully participate in society without digital literacy and will not be able to acquire the knowledge and skills required to live in the 21st century (European Commission, 2003). In the 21st-century when online learning is important, Polizzi (2020) has searched that digital literacy entails and how to promote it across the national curriculum for England. One of the ways that contribute to the development of students' digital literacy skills is to enable students to create digital stories. Studies have revealed that the digital storytelling creation process improves the technology literacy of students and they can use technology and the internet more effectively (Davis, 2004; Demirer, 2013; Dogan, 2007; Foley, 2013; Frazel, 2010, Gyabak \& Godina, 2011; Hett, 2012; Heo, 2009; Kajder, 2004; Keleş, 2018; Ranker, 2008; Robin, 2006; Robin, 2008; Sadik, 2008; Skinner \& Hagood, 2008; Wang \& Zhan, 2010). Also, digital literacy in this study means that students' skills and awareness of using digital tools with the digital storytelling created in the Turkish course. 


\section{Research questions}

The problem statement of this research has been determined as follows: "How does it explain the effect of digital storytelling on the 7th graders' digital literacy?"

The subproblems are as follows;

a) Is there a significant difference between pre-test and post-test scores of the students' digital literacy in the experimental group in which digital storytelling was applied?

b) Is there a significant difference between post-test scores of the students' digital literacy in the experimental group in which digital storytelling was applied and the ones in the control group in which it was not applied?

\section{Method}

The quantitative research method was used in this study in which the effect of digital storytelling on the digital literacy of 7 th graders at secondary school was investigated. A quasi-experimental design, which purposes to determine the cause-effect relationship between variables, was used as a research design. In the quasi-experimental paired design, two of the ready groups are aimed to be matched over certain variables, and the matched groups are randomly assigned to the operation groups (Büyüköztürk, Çakmak, Akgün, Karadeniz \& Demirel, 2012). Accordingly, the groups in this study were determined by simple random, and each study group was given an equal probability of being selected. Since the pre-test was to be used before the experiment, the study continued with the pre-test / post-test paired control group pattern, and the data were collected.

\section{Study Group}

The study group occurs 35 7th graders (12-14 years old) from a private secondary school affiliated with the Central District of Kars. The research was realized in the 7th-grade Turkish course (mother tongue) in the spring semester of the academic year 2018-2019. Before the study was started, the permission of the Ethics Committee and Governorship was obtained for the scales to be used in the research, and the aim and process of the study were explained to the school administration, Turkish language teacher, and Technology and design course teacher (Robotic Coding). Class 7-A (18 students) of a private school affiliated to the Central District of Kars province became the experimental group while Class 7-B (17 students) became the control group. The gender distribution of the groups is demonstrated in Table 1 . The reason why 7 th graders at secondary school got included in the study is that students have fully acquired the ability to create a story script consistency with the Turkish course curriculum and also a certain technology literacy that allows them to use the photoStory3 program in line with the informatics course curriculum.

Table 1. Gender distribution of the students in both control and experimental groups

\begin{tabular}{lllll}
\hline \multirow{2}{*}{ Gender } & \multicolumn{2}{l}{ Experimental Group } & \multicolumn{2}{l}{ Control Group } \\
\cline { 2 - 5 } & $\mathrm{n}$ & Percentage $(\%)$ & $\mathrm{n}$ & Percentage (\%) \\
\hline Female & 9 & 50.0 & 9 & 52.90 \\
Male & 9 & 50.0 & 8 & 47.10 \\
Total & 18 & 100 & 17 & 100 \\
\hline
\end{tabular}

As indicated in Table 1, there are 9 girls (50\%) and 9 boys (50\%) in the experimental group while there are 9 girls $(52.90 \%)$ and 8 boys $(47.10 \%)$ in the control group. It is significant for the objectivity of the study that the group and gender distribution ratios are approximate to each other. It is shown in Table 2 whether the students in the experimental and control groups have an internet connection and a computer in their houses. 
Table 2. Status of having an internet connection and a computer of the experimental and control group students

\begin{tabular}{lllllllll}
\hline & \multicolumn{3}{c}{ Experimental Group } & \multicolumn{3}{c}{ Control Group } \\
\hline \multicolumn{3}{c}{ Internet } & \multicolumn{2}{c}{ Computer } & \multicolumn{2}{c}{ Internet } & \multicolumn{2}{c}{ Computer } \\
\hline \multicolumn{2}{r}{ Percentage $(\%)$} & $\mathrm{n}$ & Percentage $(\%)$ & $\mathrm{n}$ & Percentage $(\%)$ & $\mathrm{n}$ & Percentage $(\%)$ & $\mathrm{n}$ \\
\hline Yes & 100 & 18 & 100 & 18 & 100 & 17 & 100 & 17 \\
\hline No & 0 & 0 & 0 & 0 & 0 & 0 & 0 & 0 \\
\hline Total & 100 & 18 & 100 & 18 & 100 & 17 & 100 & 17 \\
\hline
\end{tabular}

As indicated in Table 2, it is seen that all of the experimental and control group students have internet connections and computers at home. Likewise, the students added the information that all of them had smartphones in their houses in their personal information form. Since the research was conducted in a private (paid) school it is thought that all of them have an internet connection, smart mobile phones, and computers in their houses.

The pre-test scores of the experimental and control group students are as follows. In the examination of a normal distribution, it was determined that the scale scores did not prove a normal distribution. Accordingly, the Mann Whitney U test, one of the nonparametric tests, was used for pretest scores. Table 3 indicates the results of the Mann-Whitney $U$ test conducted to determine whether the difference between pre-test score averages of the experimental and control groups' digital literacy skills is significant or not.

Tablo 3. Pre-test scores of experimental and control groups' digital literacy skills

\begin{tabular}{|c|c|c|c|c|c|}
\hline & Group & $\mathbf{n}$ & $\begin{array}{c}\text { Median } \\
\text { (Min-Maks) }\end{array}$ & Mann-Whitney U & p \\
\hline \multirow{2}{*}{ Scale } & Experimental & 18 & $3.76(1.18-4.76)$ & \multirow{2}{*}{130.5} & \multirow{2}{*}{0.463} \\
\hline & Control & 17 & $3.35(1.47-4.65)$ & & \\
\hline \multirow{2}{*}{ Attitude } & Experimental & 18 & $3.42(1.00-4.43)$ & \multirow{2}{*}{138.5} & \multirow{2}{*}{0.631} \\
\hline & Control & 17 & $3.28(1.71-4.57)$ & & \\
\hline \multirow{2}{*}{ Technical } & Experimental & 18 & $3.92(1.50-5.00)$ & \multirow{2}{*}{125.5} & \multirow{2}{*}{0.362} \\
\hline & Control & 17 & $3.50(1.33-5.00)$ & & \\
\hline \multirow{2}{*}{ Cognitive } & Experimental & 18 & $3.75(1.00-5.00)$ & \multirow{2}{*}{130.5} & \multirow{2}{*}{0.448} \\
\hline & Control & 17 & $3.00(1.00-5.00)$ & & \\
\hline \multirow{2}{*}{ Social } & Experimental & 18 & $3.50(1.00-5.00)$ & \multirow{2}{*}{144.5} & \multirow{2}{*}{0.774} \\
\hline & Control & 17 & $3.00(1.00-5.00)$ & & \\
\hline
\end{tabular}

Upon examination of Table 3, it is seen that there is no statistically significant difference between the pre-test scores of digital literacy skills and its sub-factors belonging to the experimental and control groups ( $\mathrm{p}>0.05$ ). Therefore, it is possible to say that the experimental and control group students are two identical groups in terms of pre-test results based on digital storytelling and that the education planned to be provided will objectively reveal the expected differences in the experimental group.

\section{Data collection tool}

In this study, a Digital Literacy Scale and a personal information form were used.

Digital Literacy Scale was developed by Ng (2012). It consisted of 17 items and 4 sub-factors (attitude, technical, cognitive, social). It was studied with teacher candidates studying at a university in 
Australia in the original version of the scale, but Hamutoğlu, Güngören, Kaya-Uyanık, and GürErdoğan (2017) studied with students from different departments of Sakarya University Faculty of Education in the adaptation to Turkish. As a result of the adaptation study, a 4-factor structure that explained $65.78 \%$ of the total variance and overlapped with the items in the original form was obtained and the internal consistency coefficient was found as .93 for the whole scale. The measurement invariance of the scale was examined Eroğlu et al. (2019). Multi-group confirmatory factor analysis was performed with measurement invariance. With the findings obtained, it was investigated whether the Digital Literacy Scale developed for adult groups showed sufficient adaptation in the group consisting of secondary school students. Accordingly, the study was carried out in the fall semester of the 2018-19 academic year of two state secondary schools in the central district of Kars province. 451 students studying in grades 6-7-8 participated in the study. Since the linguistic equivalence and construct validity study of the scale was conducted, multiple group confirmatory factor analysis was performed by Eroğlu et al. (2019) for only measurement invariance. The relationship between items and factors could be tested in four stages with multi-group factor analysis (Meredith \& Teresi, 2006; Vandenberg \& Lance, 2000). Gregorich (2006) named these stages as formal, metric, scalar, and solid invariance (as cited in Uyar \& Kaya-Uyanık, 2019). It is not possible to provide solid invariance without providing metric and metric invariance without providing scalar and scalar invariance in this process. With their study, Eroğlu et al. (2019). have determined that the Digital Literacy Scale provides sufficient psychometric features and can be used for secondary school students.

The personal information form was composed by the researchers. It is a form that includes information such as the gender of the experimental and control group students and whether they have a computer, smart mobile phone, and the internet at home. The statement explaining that the personal information of the students will not be shared with anyone, and the information they are asked to write will only be used for this study is available in the instructions in the first part of the form. An e-mail address is also written for students who are curious about the result of the study. The instruction was also read out to the students. Students who wanted to ask questions were given the right to speak. Also The digital stories of the students were collected with the photostory 3 program.

\section{Collection and analysis of the data}

The data were obtained from the Digital Literacy Scale. The scale was applied to the experimental and control groups before the experimental procedure, and to two groups after that. Thus, the data were obtained. The data obtained were first recorded in the excel program and then in the SPSS 20.0 package program. Since the study group consisted of 35 students in total (18 students in the experimental group, 17 students in the control group), it was first analysed whether the data proved a normal distribution or not. When analysing quantitative data, parametric statistics are used for data with a normal distribution, and nonparametric statistics are used for data that do not prove a normal distribution. Since the study group of this research consisted of 35 students, the data did not indicate a normal distribution. In parallel with that, nonparametric statistics were used in this study. Mann Whitney UTest, one of the non-parametric statistics, was used to analyse whether there was a difference between the pre-test scores of the experimental and control group students and whether there was a difference between the post-test scores of the experimental and control group students. Mann Whitney U-Test is used when the distribution of scores does not meet the assumption of normality in experimental studies with few subjects where unrelated measurements are present (Büyüköztürk, 2014). Mann Whitney UTest is accepted as the equivalent of t-test in nonparametric analyses (Büyüköztürk, 2014; Can, 2014; Çepni, 2014; Taşpınar, 2017). To analyse whether there is a significant difference between the pre-test and post-test scores of the experimental group students, the Wilcoxon signed-rank test, one of the nonparametric statistics, was used. The Wilcoxon signed-rank test is used in social sciences in-group studies with few subjects (Büyüköztürk, 2014; Can, 2014; Çepni, 2014). Moreover, since the scale scores do not prove normal distribution in this study, the median (minimum-maximum) is provided instead of the arithmetic mean.

\section{Experimental process}


After the decree of the Ethics Committee and the permissions of the Governorship were received, the implementation process started in the spring term of the academic year 2018-2019. The study was conducted in a private secondary school affiliated with the Central District of Kars. It has been an essential criterion that the school should have the technological tools and equipment required to create a digital story. In the first week, the school principal was interviewed, and the aim and application process of the research was explained to her in detail. In the second week, the researchers met the teachers and explained the study. In the third week, classrooms and computer laboratories of 7th graders were examined. It was noted that the smart boards worked, the teachers' and students' computers in the laboratory operated, and there were headsets in the school. Since there was no PhotoStory3 program on computers, the program was installed on the computers with the help of the robotic coding course teacher. In the fourth week, the Digital Literacy Scale was applied to the experimental and control group students simultaneously on Wednesday. During the practice hours overlapping with Turkish and Mathematics lessons, the relevant teachers helped the researchers. The control group was not intervened during this period. The relevant teacher conducted Turkish lessons by the current curriculum (2018) until the end of the process. In the fifth week, a seminar on digital storytelling and the PhotoStory3 program was given to the experimental group students by the researcher. The students watched a sample digital story in the classroom. The students were asked to bring a flash / USB memory the following week. In the sixth week, they were asked to create a text to write a story about a place they visited or wondered about among the places they learned in the scope of the lesson. This text was to consist of a maximum of 400 words. While the students were creating their texts, the researcher uploaded the presentations about digital storytelling and the PhotoStory3 program to their memory sticks. Thus, the students were able to re-watch the presentations at home. The texts of the students who started to create texts in the classroom were assessed in the classroom, and they had the chance to make corrections thanks to the feedback. In the seventh week, they were required to collect visuals about their stories. They were taken to the computer laboratories to do that. Photographs and pictures related to their stories were collected from the websites that provide free usage. They were asked to save the collected photographs and pictures in the files they created on the computer and to upload them to their own flash memory. This, therefore, helped them back up the visuals. They were told that they could also draw pictures regarding their stories and collect images through their personal or parents' mobile phones, and cameras. However, none of the students preferred that. All of them preferred to collect the visuals on the internet. In the eighth week, a flow chart was distributed to the students. They were asked to note in this flowchart which visuals they would use on which slide in their stories, what they would dub on which slide, what effects, and music they would like to use. They were reminded that they had to create their stories in a 3-5 minute length, and they needed to calculate how many seconds each slide should pause for. During the creation of the flow charts, the researcher constantly checked the students walking around them and helped the students who asked for help. They were requested to bring their flow charts the following week. In the ninth week, the students were asked to open PhotoStory3 on their computers in the computer lab. Headsets were distributed to the students. It was ensured that they started to create their digital stories by what was there on the first page of their flow charts, which means the sentence/s, visuals, effects they wanted to add on the first slide. The students were reminded that they could dub the texts on the slides, change the font sizes and colours, make changes on the visuals, use the effects they like, and finally create the music in the instruments and tones they wanted. They were enabled to save the story they created. In the tenth week, it was provided that they could complete the missing parts of their digital stories and make the necessary corrections as they wished and finalize their digital stories. In the eleventh week, the students were encouraged to share their own digital stories in the classroom. Digital stories were watched starting with the volunteering students. The Turkish teacher also joined that. The students who wanted to speak about the digital stories were encouraged to share their opinions. In the twelfth week, the Digital Literacy Scale was applied to the experimental and control group students simultaneously on Wednesday. Teachers of the relevant lesson, whose lessons overlapped with the application time, helped the researchers. Furthermore, the students were enabled to create their digital 
stories in consideration of the six-stage story-making process suggested by Robin (2006) in the introduction. Again, they were enabled to create their digital stories according to the seven elements suggested by Barrett (2009) in the introduction.

\section{PhotoStory3 program used during the application process}

PhotoStory3 is one of the most preferred programs used to create digital stories (Sadik, 2008). It is a free-of-charge program for Windows users. Through this program, you can add photos and write over a text about a picture, make formal changes on the text, use filters for photos, add transition effects, dub the text of each slide before moving on to the next slide, and finally, the ready music can be uploaded or the person can create his own music. One of the reasons why this program is preferred is that it is free, and the other is that it contains all the elements that will be used to create a digital story. Thus, it is easier to create a digital story with a single program, and it is thought that students' anxiety will decrease, and they will not find the process difficult.

\section{Findings}

In this section, the findings of the collected and analysed data are given in tables. The findings are ranked according to the research sub-problems.

Findings regarding the first sub-problem: Is there a significant difference between pre-test and post-test scores of the students' digital literacy in the experimental group in which digital storytelling was applied?

The results of the Wilcoxon signed-ranks test showing whether there is a significant difference between pre-test and post-test scores of the experimental group's digital literacy skills are indicated in Table 4.

Tablo 4. Findings of the differences between pre test and post test scores of digital literacy scale of the experimental group students digital literacy skills and its sub-factors

\begin{tabular}{lllcc}
\hline & Pre-test & Post-test & Wilcoxon & p \\
\cline { 2 - 5 } Scale & $3.76(1.18-4.76)$ & $4.35(3.71-4.76)$ & 3.593 & $0.000^{* *}$ \\
Attitude & $3.42(1-4.43)$ & $4.28(3.86-4.71)$ & 3.638 & $0.000^{* *}$ \\
Technical & $3.91(1.5-5)$ & $4.5(3.5-5)$ & 3.209 & $0.003^{*}$ \\
Cognitive & $3.75(1-5)$ & $4(4-5)$ & 2.517 & $0.009^{*}$ \\
Social & $3.5(1-5)$ & $4(3-5)$ & 2.610 & $0.006^{*}$ \\
\hline
\end{tabular}

On examination of Table 4, it is seen that there is a significant difference between the pre-test and post-test scores of the digital literacy scale of the experimental group students digital literacy skills $(\mathrm{p}<0.01)$. At the same time, there are significant differences between pre-test and post-test scores in all sub-factors of the experimental group's digital literacy skills $(\mathrm{p}<0.05)$. When the median values of the test results are examined, it is seen that the post-test scores of the experimental group in all sub-factors of digital literacy significantly changed. It is observed that the digital literacy scores of the experimental group students increased after the experimental procedure.

Findings regarding the secondary sub-problem: Is there a significant difference between post-test scores of the students' digital literacy in the experimental group in which digital storytelling was applied and the ones in the control group in which it was not applied?

After the experimental procedure, the Mann-Whitney $U$ test was implemented to see the comparative state of the post-test scores of the experimental group and the control group, that is, whether there is a difference between the post-test scores between the groups. The Mann-Whitney $U$ test results showing whether there is a significant difference between the post-test scores of the digital literacy scale of the experimental and control groups towards digital literacy skills are indicated in Table 5. 
Tablo 5. Findings of the differences between groups in the post-test scores of the digital literacy skills

\begin{tabular}{lllcc}
\hline & Group & Post-test & Mann-Whitney U & p \\
\hline \multirow{2}{*}{ Scale } & Experimental & $4.35(3.71-4.76)$ & 47.5 & $0.000^{* *}$ \\
& Control & $3.76(1.24-4.53)$ & & \\
Attitude & Experimental & $4.28(3.86-4.71)$ & 75.5 & $0.010^{*}$ \\
& Control & $3.85(1-4.71)$ & & \\
Technical & Experimental & $4.5(3.5-5)$ & 38 & $0.000^{* *}$ \\
& Control & $3.5(1.33-4.5)$ & & \\
Cognitive & Experimental & $4(4-5)$ & 58.5 & $0.001^{* *}$ \\
& Control & $3(1-5)$ & & $0.011^{*}$ \\
Social & Experimental & $4(3-5)$ & 78 & \\
& Control & $4(1-5)$ & & \\
\hline
\end{tabular}

When Table 5 is examined, it is seen that there is a significant difference between the post-test scores of the experimental and control groups' digital literacy skills $(\mathrm{p}<0.01)$. It is apparent that the posttest scores of the experimental group are higher than the post-test scores of the control group in terms of the overall scale and sub-factors. It is seen that the digital literacy scores of the experimental group students are significantly higher than the digital literacy scores of the control group students. It can be said that digital storytelling contributes to the digital literacy skills of students.

\section{Results and Discussion}

The conclusion regarding the digital literacy skills of the 7th graders at middle school gained thanks to digital storytelling has been mentioned in this section of the study. These results were compared to similar and relevant studies in the literature. Concerning the conclusion obtained from this study, primary suggestions have been made. However, the discussion has been made by establishing a connection with the results of studies considered to have similarities with digital storytelling and digital literacy skill since no study was encountered to make a one-to-one comparison even though several studies related to the subject of this research were reached.

The first sub-problem of the research is: "Is there a significant difference between pre-test and posttest results of digital literacy of the students in the experimental group where digital storytelling was applied?" A significant difference between pre-test and post-test results of digital storytelling of the students in the experimental group where digital storytelling was applied has been discovered on behalf of post-test. This result points out that digital storytelling has a significant positive effect on digital literacy and improved students' digital literacy skills. The second sub-problem of the research is: "Is there a significant difference between the post-test results of the students in the experimental group where digital storytelling was applied and the ones in the control group where digital storytelling was not applied?". These results are parallel to the studies (Alexander, 2011; Ayvaz Tunç, 2016; Balaman Uçar, 2016; Churchill, 2016; Davis, 2004; Dogan, 2007; Foley, 2013; Frazel, 2010; Gyabak and Godina, 2011; Hett, 2012; Heo, 2009; Kajder, 2004; Karakoyun, 2014; Keleş, 2018; Morgan, 2014; Polater, 2019; Ranker, 2008; Robin, 2006; Robin, 2008; Robin, 2016; Robin, and McNeil, 2012; Sadik, 2008; Skinner and Hagood, 2008; Wang and Zhan, 2010; Yamaç, 2015; Y1lmaz, 2019) dealing with different dimensions of 21st-century skills of digital storytelling in the literature. Vasudevan, Schultz, and Bateman (2010) realized in their study that formation of digital storytelling process is a process where students become aware of the fact that they could take photos with cameras, record their voices through voice recorders 
and use basic presentation software, and it was not as scary as they thought and helped the students improve their skills to use technology. In the studies with pre-service teachers, it has been found that digital literacy levels of pre-service teachers differ significantly after the digital story creation process (Çetin, 2021; Özüdoğru \& Çakır, 2020).

Considering the reasons why digital storytelling has a significant effect on digital literacy, it is likely to say that it is related to the fact that the students have realized they can create the videos they have watched. This is associated with their capability to become active producers rather than passive consumers of multimedia thanks to their digital storytelling experience (Ohler, 2006).

Another reason why digital storytelling has a significant effect on digital literacy is the fact that the students have realized their digital stories can be more than a text and exist in a concrete form on the screen as a result of the formation process of digital storytelling. The students wanted to apply their digital literacy skills most efficiently and effectively in order to deliver them to the screen. The studies conducted also indicate that the students were able to blend their stories with multimedia elements and create their digital stories successfully (Dogan, 2007; Foley, 2013; Sylvester and Greenidge, 2009; Vasudevan, Schultz and Bateman, 2010; Yamaç, 2015).

It is possible to say that collecting visuals during the formation process of digital storytelling, dubbing, and processes of assembling the text, visuals, audio, music, and effects can be among the reasons why digital literacy levels of the students in the experimental group were higher. During the digitalization of the stories, both 21st-century skills (digital-technology-media-visual literacy) and perceptions and viewpoints of the students have been developed. Primary studies have also suggested that the formation process of digital storytelling has improved students' technology and internet literacy and enhanced their competence regarding technological tools (Davis, 2004; Demirer, 2013; Dogan, 2007; Foley, 2013; Heo, 2009; Kajder, 2004; Keleş, 2018; Ranker, 2008; Wang and Zhan, 2010). Therefore, the students have become aware of the fact that they could do a fun, educational, and instructional activity on the computer apart from playing computer games, doing tests, and preparing a homework file. Chan, Churchill, and Chiu (2017) have found in their study with three participants whose average age was twenty that digital storytelling contributed to the students' digital literacy. Chan et. al. have realized that digital storytelling has also contributed to the development of students' digital competence and adaptation to digital use and transformation as a result of their study. Yuksel, Robin, and McNeil, (2011) have emphasized that students can improve their digital literacy effectively by using technological tools such as cameras, microphones, and video editing software during the formation process of digital storytelling. The fact that multimedia elements are available during the digital storytelling formation process encourages students to use technology more effectively and improve their digital literacy necessarily (Barber, 2016; Clark, Couldry, MacDonald, \& Stephansen, 2015; Xu, Park, \& Baek, 2011).

In line with these results, considering multi-literacy skills expected from 21st-century students, it is seen that the application of digital storytelling in lessons will contribute to the development of these skills. This study was conducted at a school where families with a specific socio-economic level send their children. All the students participating in this study have internet, smartphones, and computers at home. However, the fact that there will be a difference in the development of digital literacy skills between those students and the ones with a variety of socio-economic levels should not be ignored. The studies conducted also suggest that there is a difference between the children from lower socioeconomic levels and the ones from upper socio-economic levels in terms of digital literacy (Cooper, 2004; Duveskog, Tedre, Sedano and Sutinen, 2012; Forzani ve Leu, 2012; Gyabak and Godina, 2011; Henry, 2007; Leu, Everett-Cacopardo, Zawilinski, McVerry, and O'Byrne, 2011).

Another reason why the students in the experimental group have improved their digital literacy skills more is filling in the flow chart during the formation process of digital storytelling. The flow chart is a draft scenario plan which shows how digital stories are assembled with such components as text, visual, audio, music, and effect. Kearney (2011) also suggests that it is a cognitive organizational system explaining how these components can be assembled. Even though the formation of the flow chart is 
considered as an extra stage by the students, it is actually an essential stage where students can check what is missing, modify the stories for the last time, and see them as a whole before composition, which saves their time while using the program because it allows the students to know what to do, where and when to do it, and to gain self-confidence during the process. Namely, the formation of the flow chart is a stage where the students can revise their stories for the last time (Jakes and Brennan, 2005; Kajder, 2004; Kearney, 2011; Ohler, 2006; Robin, 2006; Robin, 2008; Sadik, 2008). Formation of the flow chart stage of the digital storytelling enables the students to revise their stories one more time, which makes the stories better; therefore, it helps them develop a positive attitude towards storytelling (Eroğlu \& Eroğlu, 2020) and creates a positive effect on their digital literacy thanks to the self-confidence they have gained about what to do on which slide when they open the program to be used for digital storytelling.

Also, this study was conducted by researchers from the beginning to the end of the process. It has been noted that the study should include Barrett's (2009) suggestion of a six-phase digital storytelling composition process and Robin (2006)'s seven elements in digital stories should exist in the students' digital stories. Although some students had difficulty in the last phase, phasing, and in calculating how many seconds each slide would be, it was noticed while the formation of the flow chart. Efforts to overcome this problem were made by the researchers' amendments during the formation of the flow chart. It was seen that no significant difference based on gender was found in the analyses of the data obtained. Similarly, since all of the students both in the experimental and control groups have internet, computers, and smartphones at home, no significant finding was discovered in such terms.

\section{Conclusions}

It was found that there is a significant difference in favour of the experiment group in terms of post-test scores of digital literacy among the groups after the experiment. At the same time; it was found that there is a significant difference in favour of the post-test between the pre-test and post-test scores of the experimental group. This result points out that digital storytelling has a significant positive effect on digital literacy and improved students' digital literacy skills.

Briefly, it is revealed in this study that the digital storytelling process has contributed to the development of students' digital literacy skills.

\section{Suggestions}

Suggestions based on the study conclusion are listed below.

1. This study was conducted with 7th graders at middle school, and it was revealed that digital storytelling has a significant effect on their digital literacy skills. It is suggested that the effects of digital storytelling on digital literacy skills should be examined in different grades of education in order to reach more comprehensive results of this subject and compare the outputs in a multidimensional way.

2. It has been found in this study that digital storytelling has a significant effect on the digital literacy skills of the students taking Turkish lessons at middle school. It is suggested to examine whether similar results will be obtained in different lessons.

3. It has been found in this study that digital storytelling has a significant effect on digital literacy skills through the quantitative method. It is suggested to conduct more detailed or generalizable researches using different methods and techniques.

4. It has been found in this study that digital stories composed have a significant effect on digital literacy skills. It is suggested to examine the effect of digital storytelling on 21st-century skills, mediatechnology-visual literacy, and compare the results to its significant effect on digital literacy.

\section{Ethics Committee Approval}

Ethics committee approval for this study is available with the decision of the Sakarya University Rectorate Ethics Committee meeting 08, decision 09, on 01.01.2019.

\section{Declaration of competing interest}


None.

\section{REFERENCES}

Akbayır, S. (2007). Eğitim fakülteleri için cümle ve metin bilgisi. (Improved 5th Edition). Ankara: Pegem Akademi.

Akyol, H. (2006). Yeni programa uygun Türkçe öğretim yöntemleri. Ankara: Kök Yayıncllı.

Alexander, B. (2011). The new digital storytelling: creating narratives with new media. PRAEGER, ABCCLIO: Santa Barbara, CA, US.

Ayvaz Tunç, Ö. (2016). Dijital teknolojiler bağlamında dijital öyküleme yaklaşımının güzel sanatlar eğitimine entegrasyonu (Ph.D. thesis). Accessed from YÖK Thesis Center (No: 442983).

Babacan, M. (2008). Yazılı ve sözlü anlatım (kompozisyon bilgileri). (Improved 2nd Edition). İstanbul: 3F Yayınevi.

Baki. Y. (2015). Dijital öykülerin altıncı sinı öğrencilerinin yazma sürecine etkisi (Ph.D. thesis). Accessed from YÖK Thesis Center (No: 389155).

Balaman Uçar, S. (2016). The impact of digital storytelling on English as a foreign language learners' writing skills (Ph.D. thesis). Accessed from YÖK Thesis Center (No: 435230).

Barber, J. F. (2016). Digital storytelling: New opportunities for humanities scholarship and pedagogy. Cogent Arts \& Humanities, 3(1), Number: 1181037 DOI: 10.1080/23311983.2016.1181037

Barrett, H. (2009). Creating your digital story: a sequence of activities how to create simple digital stories. http://electronicportfolios.org/digistory/howto.html Accessed

Bilgi Teknolojileri ve İletişim Kurumu, BTK. (2018). Bilgi teknolojileri ve internetin bilinçli, güvenli kullanımı. Ankara: Bilgi Teknolojileri ve İletişim Kurumu İnternet Daire Başkanlığı.

Brenner, K. (2014). Digital stories: A 21st-century communication tool for the English language classroom. English Teaching Forum, 52(1), 22-29.

Brown, J., Bryan, J., \& Brown, T. (2005). Twenty-first century literacy and technology in K-8 classrooms. Innovate: Journal of Online Education, 1(3).

Bull, G., \& Kajder, S. (2005). Digital storytelling in the language arts classroom. Learning \& Leading with Technology, 32(4), 46-49.

Büyüköztürk, Ş. (2014). Sosyal bilimleri için veri analizi el kitabı (Improved 19th Edition). Ankara: Pegem Akademi.

Büyüköztürk, Ş., Çakmak, E.K., Akgün, Ö.E., Karadeniz Ş., \& Demirel, F. (2012). Bilimsel araştırma yöntemleri. (Improved 11th Edition). Ankara: Pegem Akademi.

Can, A. (2014). SPSS ile bilimsel araştırma sürecinde nicel veri analizi (3. Edition). Ankara: Pegem Akademi.

Chan, B. S. K., Churchill, D. ve Chiu, T. F. K. (2017). Digital literacy learning in higher education through digital storytelling approach. Journal of International Education Research, 13(1), 1-16.

Chung, S. K. (2006). Digital storytelling in integrated arts education. The International Journal of Arts Education. 4(1), 33-63.

Chung, S. K. (2007). Art education technology: digital storytelling. Art Education, 60(2), 17-22.

Churchill, N. (2016). Digital storytelling as a means of supporting digital literacy learning in an upper-primaryschool English language classroom (doctor of philosophy). Accessed from https://ro.ecu.edu.au/ theses/1774 
Ciğerci, F. M. (2015). İlkokul dördüncü sinıf Türkçe dersinde dinleme becerilerinin geliştirilmesinde dijital hikâyelerin kullanılması (Master thesis). Accessed from YÖK Thesis Center (No: 415878).

Clark, W., Couldry, N., MacDonald, R., \& Stephansen, H. C. (2015). Digital platforms and narrative exchange: Hidden constraints, emerging agency. New Media \& Society, 17(6), 919-938.

Cooper, M. (2004). Expanding the digital divide and falling behind on broadband: Why telecommunications policy of neglect is not benign. Washington: Consumer Federation of America.

Çepni, S. (2014). Araştırma ve proje çalışmalarına giriş (Geliştirilmiş 7. Baskı). Trabzon: Celepler Matbaacilik.

Çetin, E. (2021). Digital storytelling in teacher education and its effect on the digital literacy of preservice teachers. Thinking Skills and Creativity, 39, 100760.

Çıralı, H. (2014). Dijital hikâye anlatımının görsel bellek ve yazma becerisi üzerine etkisi (Master thesis). Accessed from YÖK Thesis Center (No: 378556).

Davis, A. (2004) Co-authoring identity: digital storytelling in an urban middle school. THEN: Technology, Humanities, Education and Narrative, 1, 1-12.

Dayan, G. (2017). İlkokul öğrencilerinin Türkçe dersinde dijital öyküleme çalışmaları (Master thesis). Accessed from YÖK Thesis Center (No: 482129).

Dayan, G., \& Girmen, P. (2018). Türkçe eğitimi yazma sürecinde: dijital öyküleme. Journal of Qualitative Research in Education - JOQRE, 6(3), 207-228.

Demirer, V. (2013). İlköğretimde e-öyküleme kullanımı ve etkileri (Ph.D. thesis). Accessed from YÖK Thesis Center (No: 328704).

Dogan, B. (2007). Implementation of digital storytelling in the classroom by teachers trained in a digital storytelling workshop (Ph.D. thesis). University of Houston, USA.

Doğan, D. M. (2005). Büyük Türkçe sözlük. İstanbul: Pınar Yayınları.

Duveskog, M., Tedre, M., Sedano, C. I. ve Sutinen, E. (2012). Life planning by digital storytelling in a primary school in rural Tanzania. Educational Technology \& Society, 15(4), 225-237.

Eroğlu, A. (2020a). A validity and reliability study of story writing anxiety scale. Sakarya University Journal of Education, 10(1). 120-135.

Eroğlu, A. (2020b). Türkçe öğretmeni adaylarının dijital hikâyeye yönelik metaforik algıları. RumeliDE Dil ve Edebiyat Araştırmaları Dergisi, 18, 49-60.

Eroğlu, A., \& Okur, A. (2020). The Effect of Digital Storytelling on Attitudes of the 7th Graders at Secondary School Towards Story Writing. European Journal of Education Studies, 7(12), 370-390.

Eroğlu, A., Güngören, Ö. C., Kaya Uyanık, G. ve Gür Erdoğan, D. (2019). Dijital okuryazarlık ölçeğinin ortaokul öğrencileri için ölçme değişmezliğinin incelenmesi. 7. Uluslararası Öğretim Teknolojileri ve Öğretmen Eğitimi Sempozyumu, 30 Ekim-01 Kasım 2019, Antalya, Türkiye.

Eshet, Y. (2002). Digital literacy: A new terminology framework and its application to the design of meaningful technology-based learning environments. Accessed from https://files.eric.ed.gov/fulltext/ ED477005.pdf

European Commission. (2003). eLearning: better eLearning for Europe. Belgium: Directorate-General for Education and Culture.

Foley, M.L. (2013). Digital storytelling in primary-grade classrooms (Ph.D. thesis). Arizona State University, Pheonix. 
Forzani, E. ve Leu, D. J. (2012) New literacies for new learners: The need for digital technologies in primary classrooms. The Educational Forum, 76(4), 421-424.

Frazel, M. (2010). Digital Storytelling: Guide for Educators. Eugene, OR: International Society for Technology in Education (ISTE). http://www.iste.org/images/excerpts/digsto-excerpt.pdf. Accessed

Hamutoğlu, N. B., Güngören, Ö. C., Kaya-Uyanık, G. ve Gür-Erdoğan, D. (2017). Dijital okuryazarlık ölçeği: Türkçeye uyarlama çalışması. Ege Ĕ̆itim Dergisi, 18(1), 408-429.

Göçer, A. (2014). Yazma Eğitimi - yazma uğraşı yazı nasıl yazılır? nasıl yazar olunur? Ankara: Pegem Akademi.

Günay, D. ve Şişman, B. (2018). Bilgi ve iletişim teknolojileri okuryazarlğı. A. D. Ö. ve Özçelik ve M. N. Tuğluk (Ed.), Eğitimde ve endüstride 21. yüzyıl becerileri (s. 271-290). Ankara: Pegem Akademi.

Gündüz (Dola), N. (2019). Dijital öykü yazarlığının çeşitli değişkenlere göre incelenmesi (Master thesis). Accessed from YÖK Thesis Center (No: 570395).

Gyabak, K. ve Godina, H. (2011). Digital storytelling in Bhutan: A qualitative examination of new media tools used to bridge the digital divide in a rural community school. Computers $\mathcal{E}$ Education, 57(4), 2236-2243.

Hathorn, P. P. (2005). Using digital storytelling as a literacy tool for the inner city middle school youth. The Charter Schools Resource Journal, 1(1), 32-38.

Heo, M. (2009). Digital Storytelling: an empirical study of the impact of digital storytelling on preservice teachers' self-efficacy and dispositions towards educational technology. Journal of Educational Multimedia and Hypermedia, 18(4), 405-428.

Henry, L. A. 2007. Exploring new literacies pedagogy and online reading comprehension among middle school students and teachers: Issues of social equity or social exclusion? (Ph.D. thesis). University of Connecticut, Storrs, USA.

Hett, K (2012). Technology-supported literacy in the classroom: using audiobooks and digital storytelling to enhance literacy instruction. Illinois Reading Council Journal, 40(3), 3-13.

Jakes, D.S., ve Brennan, J. (2005). Capturing stories, capturing lives: an introduction to digital storytelling. Accessed from http://www.jakesonline.org/dst_techforum.pdf

Kajder, S. B. (2004). Enter here: Personal narrative and digital storytelling. The English Journal, 93(3), 6468.

Karakoyun, F. (2014). Çevrimiçi ortamda oluşturulan dijital öyküleme etkinliklerine ilişkin öğretmen adaylar ve ilköğretim öğrencilerinin görüşlerinin incelenmesi (Ph.D. thesis). Accessed from YÖK Thesis Center (No: 361705).

Kavcar, C., Oğuzkan F., ve Aksoy, Ö. (2003). Yazılı ve sözlü anlatım (3. Edition). Ankara: Anı Yayıncılık.

Kearney, M. (2011). A learning design for student-generated digital storytelling. Learning, Media and Technology, 36(2), 169-188.

Keleş, D. (2018). Öğretmen adaylarının tekno-stres incelenmesi: dijital hikâye örneği (Master Thesis). Accessed from YÖK Tez Merkezi veri tabanından erişildi (No: 507905).

Koltay, T. (2011). The media and the literacies: media literacy, information literacy, digital literacy. Media, Culture \& Society, 33(2), 211-221.

Lambert, J. (2010). Digital storytelling cookbook. Berkeley: Digital Diner Press. ISBN: 978-0-9726440-1-3

Lammers, W. P. (2012). Digital storytelling: building 21st century literacy skills in the secondary classroom (Master thesis). University of Northern Iowa. 
Lankshear, C. ve Knobel, M. (2008). Digital literacies-concepts, policies and practices. Peter Lang Inc., International Academic Publishers. ISBN-10: 1433101696

Leu, D. J., Everett-Cacopardo, H., Zawilinski, L., McVerry, J. G. \& O’Byrne, W. I. (2011). New literacies of online reading comprehension. Accessed from https://newliteracies.uconn.edu/wp-content/uploads/ sites/448/2014/07/Leu-D.J.-Everett-Cacopardo-H.-Zawilinski-L.-McVerry-J.G.O\%E2\%80\%99Byrne-W.-I.-2012.-.pdf

Martin, A. \& Grudziecki, J. (2006). DigEuLit: Concepts and tools for digital literacy development. Innovation in Teaching and Learning in Information and Computer Science, 5(4), 249-267.

Matthews, J. (2014). Voices from the heart: The use of digital storytelling in education. Community Practitioner, 87(1), 28-30.

MEB. (2018). Türkçe dersi öğretim programı (ilkokul ve ortaokul 1, 2, 3, 4, 5, 6, 7 ve 8. sınıflar). MEB: Ankara.

MEB. (2006). Illköğretim Türkçe dersi (6,7,8. sinıflar) öğretim programı. Ankara: MEB.

Meredith, W. \& Teresi, J. A. (2006). An essay on measurement and factorial invariance. Medical Care, 44(11, Suppl 3), 69-S77.

Millı̂ Eğitim Bakanlığı Eğitimi Araştırma ve Geliştirme Dairesi Başkanlığı, EARGED. (2011). MEB 21. yüzyıl öğrenci profili. Ankara: Eğitimi Araştırma ve Geliştirme Dairesi Başkanlığı.

Morgan, H. (2014). Using digital story projects to help students improve in reading and writing. Reading Improvement, 51(1), 20-26.

$\mathrm{Ng}$, W. (2012). Can we teach digital natives digital literacy? Computers \& Education, 59, 1065-1078.

Ohler, J. (2006). The world of digital storytelling. Educational leadership, 63(4), 44-47.

Özerbaş, M. A. \& Öztürk, Y. (2017). Türkçe dersinde dijital hikâye kullanımının akademik başarı, motivasyon ve kalıclık üzerinde etkisi. TÜBAV Bilim, 10(2), 102-110.

Özüdoğru, G., \& Çakır, H. (2020). An investigation into the opinions of pre-service teachers toward uses of digital storytelling in literacy education. Participatory Educational Research (PER), 7(1), 242-256.

Qiongli, W. (2009). Commercialization and digital storytelling in China. (Ed. J. Hartley \& K. McWilliam). Story Circle Digital Storytelling Around the World. (ss. 239-244). USA: Blackwell Publishing.

Polater, C. (2019). Illkokul dördüncü sınfta dijital öykü yöntemiyle değerler eğitimi (Master thesis). Accessed from YÖK Thesis Center (No: 568604).

Polizzi, G. (2020). Digital literacy and the national curriculum for England: Learning from how the experts engage with and evaluate online content. Computers $\&$ Education, 152, 1-13.

Pool, C. R. (1997). A conversation with Paul Gilster. Educational Leadership, 55(3), 6-11.

Ranker, J. (2008). Composing across multiple media a case study of digital video production in a fifth grade classroom. Written Communication, 25(2), 196-234.

Razmi, M., Pourali, S., \& Nozad, S. (2014). Digital storytelling in EFL classroom (oral presentation of the story): a pathway to improve oral production. Procedia-Social and Behavioral Sciences, 98, 1541-1544.

Reinders, H. (2011). Digital storytelling in the foreign language classroom. ELTWO Journal, 3, 1-9.

Robin, B. R. (2006). The educational uses of digital storytelling. in society for information. Technology $\mathcal{E}$ Teacher Education International Conference. http://digitalstorytelling.coe.uh.edu/articles/EducUses-DS.pdf Accessed

Robin. B. R. (2008). Digital storytelling: a powerful technology tool for the 21st century classroom. Theory into Practice, 47, 220-228. 
Robin, B. R. (2016). The power of digital storytelling to support teaching and learning. Digital Education Review, 30, 17-29.

Robin, B. R., \& McNeil, S. G. (2012). What educators should know about teaching digital storytelling. Digital Education Review, 22, 37-51.

Sadik, A. (2008). Digital storytelling: a meaningful technology-integrated approach for engaged student learning. Educational Technology Research and Development, 56(4), 487-506.

Saritepeci, M. (2021). Students' and parents' opinions on the use of digital storytelling in science education. Technology, Knowledge and Learning, 26, 193-213.

Sharp, B., Garofalo, J. \& Thompson, A. (2004). Digital images in the mathematics classroom. Learning and Leading with Technology, 31(8), 30-32.

Shrosbree, M. (2008). Digital video in the language classroom. The JALT CALL Journal, 4(1), 75-84.

Simmons, A. (2008). Hikâyenin gücü. (Çev. Gökçesu Tamer). İstanbul: MediaCat Kitapları.

Skinner, E. \& Hagood, M. (2008). Developing literate identities with English language learners through digital storytelling. The Reading Matrix, 8(2), 12-38.

Sylvester, R., \& Greenidge, W. (2009). Digital storytelling: extending the potential for struggling writers. Reading Teacher, 63( 4), 284-295.

Smeda, N., Dakich, E., \& Sharda, N. (2012). Transforming Pedagogies Through Digital Storytelling: Framework and Methodology. 206-211.

Soler Pardo, B. (2014). Digital storytelling: a case study of the creation, and narration of a story by EFL learners. Digital Education Review, 26, 74-84.

Stewart, K., \& Gachago, D. (2016). Being human today: A digital storytelling pedagogy for transcontinental border crossing. British Journal of Educational Technology, 47(3), 528-542.

Stojke, A. E. (2009). Digital storytelling as a tool for revision (Ph.D. thesis). Oakland University.

StoryCenter (11.10.2017). https://www.storycenter.org/ Accessed

Taşkaya, S. M. (2017). Dil ve edebiyat öğretimi yöntemleri. A. Akkaya (Ed.), Dil ve Edebiyat Öğretimi (ss. 99-198). Ankara: Asos Yayınları.

Taşpınar, M. (2017). Sosyal bilimlerde SPSS uygulamalı nicel veri analizi. Ankara: Pegem Akademi.

TDK (WEB). Accessed from http://www.tdk.gov.tr/

Temizkan, M. (2014). Yaratıcı yazma süreci (hikâye yazma). Ankara: Pegem Akademi.

Temizyürek, F. (2003). Türkçe öğretiminde çocuk edebiyatının önemi. Türklük Bilimi Araştırmaları, 13, 161-167.

Türe Köse, H. B. (2019). Okul öncesi dönem çocuklarında dijital hikâye anlatımının dinleme becerilerine etkisi (Master thesis). Accessed from YÖK Thesis Center (No: 536853).

Uslu, A. (2019). İşbirlikli dijital hikaye anlatımının ilkokul 4. sını öğrencilerinin yaratıcı yazma ve sosyal duygusal öğrenme becerilerine etkisi (Master thesis). Accessed from YÖK Thesis Center (No: 557640).

Uyar, Ş. \& Kaya-Uyanık, G. (2019). Fen bilimlerine yönelik öğrenme modelinin ölçme değişmezliğinin incelenmesi: PISA 2015 örneği. Kastamonu Education Journal, 27(2), 297-507.

Vanderberg, R. J. \& Lance, C. E., (2000). A Review and synthesis of the measurement invariance literature: Suggestions practices, and recommendations for organizational research. Organizational Research Methods, 3, 4-70. 
Vasudevan, L., Schultz, K., \& Bateman, J. (2010). Rethinking composing in a digital age: Authoring literate identities through multimodal storytelling. Written Communication, 27(4), 442-468.

Verdugo, D. R., \& Belmonte, I. A. (2007). Using digital stories to improve listening comprehension with Spanish young learners of English. Language Learning \& Technology, 11(1), 87-101.

Xu, Y., Park, H., \& Baek, Y. (2011). A new approach toward digital storytelling: an activity focused on writing selfefficacy in a virtual learning environment. Journal of Educational Technology \& Society, 14(4), 181-191.

Walsh, B. \& Blewitt, P. (2006). The effect of questioning style during story book reading on novel vocabulary acquisition of preschoolers. Early Childhood Education Journal, 33(4), 273-278.

Wang, S., \& Zhan, H. (2010). Enhancing teaching and learning with digital storytelling. International Journal of Information and Communication Technology Education, 6(2), 76-87.

Yamaç, A. (2015). Illkokul üçüncü sını öğrencilerinin yazma becerilerinin gelişiminde dijital hikâyelerin etkisi (Ph.D. thesis). Accessed from YÖK Thesis Center (No: 397437).

Yılmaz, M. (2019). Program görselleştirme aracıyla gerçekleştirilen dijital öyküleme etkinliklerinin yaratıcı problem çz̈zme becerisi ve bilgisayara yönelik tutumuna etkisi (Master Thesis). Accessed from YÖK Tez Merkezi (No: 589843).

Yılmaz, Y., Üstündağ, M. T., \& Güneş, E. (2017). Öğretim materyali olarak dijital hikâye geliştirme aşamalarının ve araçlarının incelenmesi. Abant İzzet Baysal Üniversitesi Eğitim Fakültesi Dergisi, 17(3), 1621-1640.

Yuksel, P., Robin, B. R., \& McNeil, S. (2011). Educational uses of digital storytelling around the world. Paper presented at the Proceedings of Society for Information Technology \& Teacher Education International Conference. 